\title{
Immigrants in the Netherlands: Second-class Citizens? The Polish Case
}

\begin{abstract}
This article discusses significant problems faced by Polish citizens who live in the Netherlands and who declare their willingness to remain there for the coming years despite the unfair treatment directed towards them. The author elaborates on the history of Polish immigrants in the Netherlands after the Second World War in order to: (1) highlight the Poles' input into the liberation of the Netherlands during the war and the country's post-war development; and (2) show mutual, ambivalent PolishDutch relations between the immigrants and the host society. Based on subject literature, Dutch scientific reports, analyses and surveys, the current situation of Poles is described in the light of unchanging and thus relatively similar problems (despite the passage of time) experienced by Poles living and working in the Netherlands.
\end{abstract}

Keywords: Immigrants, The Netherlands, Discrimination, Polish Diaspora

\section{Introduction}

The tolerance and openness of the Dutch towards "others" are nowadays considered to be problematic issues. The situation in the country, for a long time recognised as an "oasis of happiness" for immigrants from around the world, has been affected by the recent refugee crisis. Multiple reports and scientific analyses show that it has activated the part of Dutch society that does not accept the constantly rising numbers of immigrants

* Violetta Gul-Rechlewicz - Jan Kochanowski University in Kielce, e-mail: violetta.gul-rechlewicz@ujk.edu.pl, ORCID: 0000-0002-6471-2395. 
coming to the Netherlands. Among residents of non-Dutch origin, who do not feel welcome by the Dutch, are Turks and Moroccans, i.e. immigrants whose history in the Netherlands dates back to the 1960s. Next to them are immigrants from Central and Eastern Europe (CEE), whose significant numbers continued to come to the Netherlands with the subsequent enlargements of the European Union (EU). Poles constitute the largest group among them and also feel the lack of acceptance from the native Dutch. They find it difficult to establish contacts with native inhabitants of the Netherlands and are said to experience different forms of discrimination.

This article discusses significant problems faced by Polish citizens who live in the Netherlands and declare their willingness to remain there for the coming years despite unequal treatment directed towards them. The history of Polish immigrants in the Netherlands after the Second World War is presented in order to: (1) highlight the Poles' input into the liberation of the Netherlands during the war and the country's post-war development; and (2) show mutual, ambivalent Polish-Dutch relations between the immigrants and the host society. Based on subject literature, Dutch scientific reports, analyses and surveys, the current situation of Poles is described in the light of unchanging and thus relatively similar (despite the passage of time) problems experienced by Poles living and working in the Netherlands.

\section{"Liberators and Builders": The History of Polish Diaspora in the Netherlands}

Poles are not only one of the largest immigrant groups in the Netherlands but also one of the oldest in terms of history of settlement. The Polish diaspora in the Netherlands consists primarily of descendants of economic migrants from the interwar period and refugees that came here in the aftermath of the Second World War. They settled in this country in different periods of history, seeking shelter and a better life. One can distinguish six stages in the history of Polish migration to the Netherlands: (1) religious migration of the Polish Brethren (Arians), who came to the Netherlands after $1638 ;^{1}$

${ }_{1}$ Dutch scientists, Wim Willems and Hanneke Verbeek, recognise three periods in the history of Polish migration to the Netherlands, based on the size of the Polish diaspora: 1900-1945, 1945-1990 and 1990 until today. Nevertheless, Dutch historiography offers no significant publications that would describe Polish migration to the Netherlands. Compared to other European countries, such as France, Germany, United Kingdom or Belgium, the tradition of Polish migration to the Netherlands seems rather insignificant, which partially explains the lack of historical sources. 
(2) political migration of people who participated in Polish national uprisings (1830-1831 and 1863); (3) economic migration in 1908-1939; (4) refugee migration (due to the Second World War); (5) post-"Solidarity" migration (triggered by the introduction of the martial law and the fall of the communist regime in Poland); and (6) "post-accession" migration that ensued after Poland joined the EU. Throughout this period spanning over 100 years, the Netherlands has become a second home to many Polish people who fought for it, worked in it and built it. During the Second World War, Polish soldiers under the command of General Maczek and General Sosabowski liberated Dutch cities and towns (e.g. Breda, Ter Apel, Winschoten, Westerdtende, Mooburg, Halterstede) from the hands of the German occupier, showing extraordinary heroism and losing their lives (e.g. the bloody Battle of Arnhem). After that, some of them decided to settle down in the Netherlands.

After the end of the Second World War, the largest Polish communities (initially in Zealand; a province in the south-west of the Netherlands) consisted largely of demobilised soldiers of the Polish $1^{\text {st }}$ Armoured Division under command of General Maczek and Polish displaced persons (DPs), including prisoners of war and prisoners of concentration camps and forced labour camps. The distribution of the Polish community in the Netherlands back then was dictated by the conditions on the labour market. The attitude towards them was similar to the one adopted presently with respect to DPs from Africa in the context of the current refugee crisis. In 1945, the Dutch government offered Polish soldiers work in mining and heavy industry, with a possibility for naturalisation after five years of continuous employment. ${ }^{2}$ Consequently, Polish immigrants settled mainly in the mining region in Limburg (Brunssum, Heerlen, Hoensbroek, Heerlerheide) and large cities, such as Amsterdam, Rotterdam and The Hague. ${ }^{3}$ In 1946-1947, approximately 2,300 soldiers came to the Netherlands, having served their time in Polish Guard Companies in Germany after the war. In that period (and also in 1948), next groups of DPs (2,855 people) continued to come and stayed in the Netherlands. ${ }^{4}$ In

2 W. Eder, Diaspora polska w Belgii i Holandii (Polish community in the Benelux The Netherlands), in: Polska diaspora (Polish community in Europe), eds. K. Kaczmarski, M. Krzysztofiński, Kraków 2003, p. 201.

3 J.A. Radomski, Demobilizacja Polskich Sit Zbrojnych na Zachodzie w latach 19451951 (Demobilization of the Polish Armed Forces in the West in 1945-1951), Kraków 2009, p. 147.

${ }^{4}$ Central Archives of Modern Records (AAN), Ministry of Foreign Affairs, General Representative for Repatriation, Letter No 503 from the Central European Department of the Ministry of Foreign Affairs to the Polish Military Mission in Berlin dated 16 October 1947. 
1947, the Netherlands agreed to accept and employ approximately 2000 former soldiers from the $1^{\text {st }}$ Armoured Division of General Maczek, who participated in the liberation of the Netherlands.

In addition to citizenship, the Polish soldiers were granted, by virtue of a royal decree, the title of honorary citizens of the Netherlands as a token of gratitude of the Dutch nation. ${ }^{5}$ According to Władysław Eder, approximately 300 of them decided to stay in the Netherlands for good. At that time, the Polish community counted approximately 6000 people. $^{6}$ The official census of 31 May 1947 reported 5,203 Poles living in the Netherlands. ${ }^{7}$ Apart from General Maczek's soldiers, there were also soldiers from the Polish $2^{\text {nd }}$ Corps under the command of General Anders (approximately 30\% of the Corps). In March 1947, the negotiations between the Polish Resettlements Corps and the British Government resulted in a Dutch recruitment unit obtaining the permission to admit approximately 3,000 Poles, who were to be employed in industry: 2000 in factories and enterprises, and 1,000 in mines. ${ }^{8}$ Post-war immigrants were more scattered across the Netherlands than their predecessors (from 19081939). Large groups of them were present nearly throughout the entire country, including Limburg, Brabant, central Holland, the province of Holland and Zeeland. ${ }^{9}$

Interestingly enough, the Limburg mines employed Polish workers already before the First World War, with most of them recruited from the Prussian Partition. According to Ryszard Żelichowski, there are many studies on Polish migrants working in different parts of the Kingdom of the Netherlands in various historical periods. However, the history of the employment of Polish soldiers after the Second World War (including Polish DPs) has not been explored to its full extent by Polish researchers, despite an abundance of sources available in Dutch. Żelichowski emphasises the unique situation of the recruited Poles - not many people were ready to do such hard labour, and with the dynamic growth of the economy labour shortages in the market could only partially be covered

${ }^{5}$ J. Balicki, Amsterdamskie ABC (Amsterdam ABC), Warsaw 1974, p. 70.

6 W. Eder, Polonia w krajach Beneluksu - Holandia, in: Polonia w Europie (Polish community in the Benelux - The Netherlands), ed. B. Szydłowska-Ceglowa, Poznań 1992, pp. 497-498.

7 Polonia Zagraniczna 1929-1954. Ksiega Pamiqtkowa w 25-lecie istnienia Światowego Zwiazku Polaków z Zagranicy (Commemorative Book on the 25th anniversary of the World Union of Poles from abroad), London 1956, p. 76.

8 R. Żelichowski, Stosunki polsko-holenderskie w Europie pojattańskiej (PolishDutch relations in post-Yalta Europe), ISP PAN, Warsaw 2014, p. 230.

9 A. Nadolny, Polonia Holenderska (Polish community in the Netherlands), "Studia Polonijne”, vol. 1/1976, pp. 126-127. 
by prisoners of war and political prisoners. ${ }^{10}$ Throughout this time, the attitude of people from Limburg generally reflected the one adopted in the state policy towards immigrants. Until the outbreak of the First World War, Limburgians considered work in the mines as an act of desperation and looked down on mass-employed foreigners who dared to work underground. The Dutch peasants, who in fact neither knew nor understood the newcomers, perceived them as a newly formed proletariat group that did not fit into the local traditions and customs.

Similarly, the Church was distrustful of industrialisation in this part of the country and the resulting influx of employees who represented different, also non-Catholic, religions and cultures. Moreover, the Church feared secularisation of society and moral breakdown, which it linked to the birth of socialism. ${ }^{11}$ Similarly to the 1920 s, work in mines was not held in high regard by the Dutch, who took it only when necessary, treating it as a temporary solution. Poles, Czechs and Slovenes (collectively referred to as a "Slavic wave"), who came to the Limburg mines at that time, were treated as indispensable workforce, employees who "were not afraid of the darkness or danger in the mines". In addition, which was very important, "they had small needs". ${ }^{12}$ Approximately 3000 workers were recruited, also from other CEE countries. In the times of the 1930s economic crisis, Poles suffered the most as the primary victims of layoffs in mines. Not only did they lose their jobs but also the roof over their heads, and in many cases they were forced to leave the Netherlands. Hours of perilous work underground often gave no future prospects and often cost miners their health. ${ }^{13}$

In the post-war period, Poles - particularly soldiers-liberators - enjoyed a special status in the Netherlands. Even many months after the liberation, thank-you notes were displayed in nearly every window which read: "Thank you, Poles". ${ }^{14}$ On 11 November 1944, the anniversary of Poland regaining its independence, Mayor of Breda Bartholomeus W. T. van Slobbe expressed the gratitude of the Dutch for Poles' participation in the liberation of the city by saying: "We will never forget it. We, the Dutch, have always been very fond of Your Nation". ${ }^{15}$ Nevertheless, not all residents were so

${ }^{10}$ R. Żelichowski, op. cit., pp. 223-226.

11 W. Willems, H. Verbeek, Sto lat tęsknoty. Polacy w Holandii (One hundred years of longing. Poles in the Netherlands), Wydawnictwo DIG, Warsaw 2014, p. 25.

12 Tekort aan mijnwerkers (Shortage of miners), (Het Nederlandse element in mijnstreek gaat achteruit) (The Dutch element in the mining region is deteriorating), „Limburger Koerier“, 13 August 1929.

13 W. Willems, H. Verbeek, op. cit., pp. 31-33.

14 Ibidem, p. 116.

15 73. rocznica wyzwolenia Bredy przez Dywizje gen. Stanistawa Maczka (73 ${ }^{\text {rd }}$ anniversary of the liberation of Breda by the Division under General Stanistaw Maczek), 
friendly towards Polish soldiers. Many of them had no idea where Poland was. ${ }^{16}$ On the one hand, Poles were given an enthusiastic welcome - they would be invited to Dutch people's houses and treated very kindly; on the other, they were never fully accepted. Dutch women were criticised for seeking relations with Polish soldiers not only by the Dutch Church but also by local social committees. Priests called for restraint in contacts with foreigners (which often ended in marriages) and talked about cultural differences, different morality, traditions and customs. ${ }^{17}$

Even the unit responsible for recruiting people for the mining industry had very high expectations. It looked for young, uneducated, single people under the age of 25 years, to whom they did not guarantee the possibility of obtaining the Dutch citizenship. In addition, a special stipulation was included in their contract of employment that "an employee may be sent to Poland if he provides false information about himself or if during his stay in the Netherlands he engages in internal or foreign politics". ${ }^{18}$ Consequently, the requirements of the Dutch tended to discourage Polish soldiers from settling in the Netherlands rather than encourage them. As Żelichowski reports, only 351 of them (which corresponded to only $1 / 3$ of possible employees expected from this group) agreed to the Dutch offer. He also quotes another interesting example as a testimony to the attitude of the Dutch towards Poles - the introduction of cards and passports that authorised Poles to camp only in strictly designated areas. This decision of the Dutch authorities was dictated by their concern for natural environment which Poles - as "negligent people" - could destroy. ${ }^{19}$

In the face of workforce shortages in many crucial areas of Dutch economy, the recruiting team targeted also displaced persons. Polish DPs were given a guarantee of employment under the Agreement of 15 July 1947 regarding the nature of the contract. The Agreement listed 10 items, two of which are particularly worth quoting. Item 3 of the Agreement stipulated "the possibility to consider their [i.e. immigrants - VGR] naturalisation after five years", thus giving Polish employees no guarantee

http://dzieje.pl/artykulyhistoryczne/rocznica-wyzwolenia-bredy-przez-1-dywizjepancerna-gen-maczka (access 12.04.2020), see also: K. Śledziński, Czarna Kawaleria. Bojowy szlak pancernych Maczka (Black Cavalry. Maczek's armored battle route), Znak, Kraków 2011.

${ }_{16}$ After the warfare in Breda ended on 29 October 1944, many of the city's inhabitants were surprised to see the inscription "Poland" on Polish soldiers' uniforms, as they were not even aware of Poland's existence, in: W. Willems, H. Verbeek, op. cit., pp. 115-116.

17 Ibidem, p. 117.

18 R. Żelichowski, op. cit., p. 235.

19 Ibidem, pp. 236-237. 
of permanent residence in the Netherlands and essentially violating one of the basic human needs - the need for safety; while Item 10 contained the provision that "only single people could be employed". ${ }^{20}$ Naturally, this recruitment style did not meet with the enthusiasm among the recruited. Explaining the strict requirement of Item 10, the Dutch government said that the Netherlands were already overpopulated and thus unable to accept Polish families. However, despite the said overpopulation, an argument often raised also by local experts, ${ }^{21}$ some years later (in the 1960s) the Dutch government decided to invite a dozen or so of employees or "guest workers" (in Dutch: gastarbeider) from the Mediterranean basin. These were subsequently followed by their families who came to the Netherlands in the 1970s, pursuant to applicable legal regulations (e.g. family reunification policy). Nowadays, the fourth generation of this group of immigrants lives in the Netherlands.

The post-war atmosphere of rather complicated relations between the Dutch and Poles is reflected in a report of one of the Dutch teams responsible for recruiting Polish employees: “(...) These people [i.e. Poles - VGR] perceived the Netherlands as an unfriendly country. They opposed our recruitment method, calling it a slave trade (...)". ${ }^{22}$ Due to tensions and controversies, eventually only 1423 people came to Dutch Limburg. ${ }^{23}$ Their arrival was met with a fierce, albeit not common, protest among others from local trade unions (e.g. De Algemene Bond van Werknemers van de Mijnen, ABWM), which treated them as a "foreign element" and a source of "civilisational degradation". The Ons Orgaan newsletter prepared a brief text about Poles, calling them "the immoral and burdensome poor", while "De Limburger" labelled them as "thugs ready to rob people" and "outsiders who will bring savagery to local jobs and local culture". ${ }^{24}$ On the other hand, little or no information was offered about the tragedy of the Polish nation during the Second World War and the heroism of Polish soldiers, who also fought for the liberation of the Netherlands.

The first Polish DPs who arrived in Limburg were enrolled in the programme of Dr. Poels, which - despite certain strategic values - was not entirely approved of by the target group. Accommodated in boarding

20 Ibidem, p. 244.

${ }^{21}$ M. Bruquetas-Callejo, B. Garcés-Mascareñas, R. Penninx, P. Scholten, Migration policymaking in Europe: the dynamics of actors and contexts in past and present, The case of the Netherlands, Amsterdam 2011, p. 129.

22 R. Żelichowski, op. cit., p. 245.

23 Ibidem, p. 249.

${ }^{24}$ Ibidem, pp. 250-251. 
schools (in Dutch: gezellenhuizen) and provided care, ${ }^{25}$ Poles did not feel well in new conditions. Feeling isolated from local people, forced to live in an unfamiliar culture of "order and discipline", without access to sport and entertainment facilities, with low-quality or insufficient food, poor medical care and "antisocial regulations" (e.g. their families were not allowed to join them), they would often decide to leave or in extreme situations (e.g. the boarding school at the Maurits mine) - even go on strike. Poles worked exclusively underground, with no chance for a promotion. Some of them claimed that they were given false information during the recruitment process about the working and housing conditions (e.g. employees of the Oranje-Nassau IV mine) ${ }^{26}$ Until they were allowed to leave their gezellenhuizen (for which they needed to obtain a permission from the Labour Office before they could go to the Allied Zone), Polish employees had to remain in their lodgings or else they would be arrested. According to Dutch law, they "posed a threat to society" just by being there in the streets. In practice, however, no such arrests were ever made.

Nevertheless, some Polish DPs did agree to work in mines for various reasons. In total, $72 \%$ of them fulfilled their contractual obligations after which they were transferred to other sectors of the Dutch economy. A high percentage of Poles stayed in the Netherlands for good or settled just across the border, in Belgium. Some of them hoped to return to Poland, while many others emigrated to the United States and Canada. Eventually, the Dutch started looking at Polish employees more favourably. Working hard and diligently, Poles gradually earned the trust of their employers who praised them for their "skills and discipline" compared to other mine workers. ${ }^{27}$

\section{Poles in the Netherlands After 2000: Issues Related to Discrimination and Inequality of Treatment}

Since 2000, the number of Poles settling in the Netherlands has risen nearly fivefold, and it has been growing steadily since Poland joined the EU in 2004. The Netherlands became a particularly attractive destination for Poles in early 2007, when pursuant to the relevant provisions in the Treaty of the EU, and other legal acts, free

25 DPs had access to libraries in boarding schools. Trips, film screenings, readings, etc. were organised for them. They could go to church and attend masses in Polish. See: R. Żelichowski, op. cit., p. 253.

${ }^{26}$ Ibidem, p. 255.

${ }^{27}$ Ibidem, pp. 256-258. 
movement of employees was introduced on the Dutch labour market. ${ }^{28}$ The Netherlands Institute for Social Research (SCP, Sociaal en Cultureel Planbureau) reports that in 2017 there were nearly 160,000 Poles living in the Netherlands, while further 90,000 were looking for seasonal work. As a result, Poles constitute the sixth largest group of immigrants residing in the Netherlands (after Turks, Moroccans, Surinamese, Indonesians and Germans). ${ }^{29}$

In a study conducted by SCP on a sample of 1,000 people, threequarters of Polish respondents declared their willingness to stay in the Netherlands for at least the next five years, with over 50\% raising their children in this country. The report also shows that the longer Poles live in the Netherlands, the better their living conditions are. In total, 37\% of Polish immigrants (particularly those who have lived in the Netherlands for a longer time) own a house..$^{30}$ On the other hand, data shows that Poles have problems establishing long-lasting relationships with native Dutch (e.g. most marriages are between people of Polish origin) and are reported to experience inequality of treatment from the Dutch. In total, $44 \%$ of Poles would like to have closer contacts with the Dutch (also long-term). Insufficient knowledge of the Dutch language in the Polish community seems to be an obstacle here, as only $10 \%$ of Poles declare that they can use it at an acceptable level. Despite these discomforts, Polish immigrants in the Netherlands evaluate their stay at 7.1 on a 10-point scale. ${ }^{31}$

As mentioned before, the number of Poles coming to the Netherlands has been on the rise since Poland joined the EU. They include people who settle here for longer as well as seasonal workers who constitute additional

${ }_{28}$ Article 3(2) of the Treaty on European Union (TEU); Art. 4(2a), art. 20, 26 and 45-48 of the Treaty on the Functioning of the European Union (TFEU); Directive $2004 / 38 / \mathrm{EC}$ on the right of citizens of the Union and their family members to move and reside freely within the territory of the Member States; Regulation (EU) No 492/2011 on freedom of movement for workers within the Union; Regulation (EC) No 883/2004 on the coordination of social security systems and Regulation (EC) No 987/2009 laying down the procedure for implementing Regulation (EC) No 883/2004.

${ }^{29}$ Only in 2016, i.e. at the time of an increased influx of refugees from Syria, was the number of Polish immigrants lower than that of Syrian asylum seekers. See: https://www.cbs.nl/nl-nl/nieuws/2016/24/150-duizend-inwoners-van-poolseherkomst (access 12.05.2020).

30 S. Wolf, Polse arbeidsmigranten in Nederland (Polish labor migrants in the Netherlands), https://www.kis.nl/sites/default/files/bestanden/Publicaties/Poolse-arbeidsmigranten-in-Nederland.pdf (access 12.05.2020).

31 https://www.dutchnews.nl/news/2018/04/polish-community-in-nl-works-hardfor-low-pay-and-wants-to-stay/?utm_source=newsletter (access 25.04.2020). 
labour force in the sector of greenhouse horticulture and agriculture. ${ }^{32}$ Studies show that $75 \%$ of Poles residing in the Netherlands have found employment in this country. ${ }^{33}$ However, most of them work physically, long hours and on temporary contracts. As SCP reports, horticulture and agriculture rely heavily on seasonal workers from Poland. The attempt to employ Dutch people from Westland, a part of the municipality of Rotterdam, for gardening and related works proved unsuccessful and came to be known as a "failed experiment" (in Dutch: Het mislukte experiment), which seems to only confirm the previous thesis. ${ }^{34}$ It is also reminiscent of the times when Polish employees were recruited for the Limburg mines. There are not many people in the Netherlands who would agree to work in these sectors on terms and conditions offered to Poles. On the other hand, Poles are recognised as reliable, diligent and flexible workers and therefore a guarantee of economic growth, particularly in the sector of agriculture. At the same time, they make two thirds of what native Dutch are paid, while $17 \%$ of Polish citizens in the Netherlands live in poverty. Lower earnings of Poles compared to Dutch people, is a particularly problematic issue in the case of women. SCP reports that they are often offered jobs below their qualifications and education levels, ${ }^{35}$ which forces them to settle for a lower pay. ${ }^{36}$

32150 duizend inwoners van poolse herkomst (150 thousand inhabitants of Polish origin), 13 June 2016, https://www.cbs.nl/nl-nl/nieuws/2016/24/150-duizend-inwonersvan-poolse-herkomst (access 27.04.2020).

${ }^{33}$ Compared to only $20 \%$ of non-Western immigrants who are employed in the Netherlands.

34150 duizend inwoners van poolse herkomst (150 thousand inhabitants of Polish origin), 13 June 2016, https://beta.volkskrant.nl/nieuws-achtergrond/poolse-migranten-zijnsteeds-vaker-van-plan-in-nederland-te-blijven $\sim$ bc10c806/?utm_term $=56238 \& u$ utm campaign $=20180424 \% 7$ Cochtend $\& u$ tm_medium $=$ email $\& u \bar{t}$ _m_userid $=\& u t m$ source $=$ VK\&utm_content $=$ Poolse $\% 20$ migranten $\% 20$ integreren $\% 20$ moeilijk $\% 20 \mathrm{in} \% 20$ Nederland,\%20maar\%20zijn\%20toch\%20steeds\%20vaker\%20van\%20plan\%20om\%20 te\%20blijven\&ctm_ctid=00a5f9469946e74995011c4af273a7f3 (access 27.04.2020).

${ }^{35}$ Dutch employers' reluctance to employ educated and qualified employees from CEE may originate from stereotypes and prejudice and the resulting psychological barrier. In addition, there are no systemic solutions in the labour policy of the state. From: M. Bos-Karczewska, Sytuacja polskiej migracji zarobkowej w Holandii a polityka państwa - nowe wyzwania (The situation of Polish labor migration in the Netherlands and state policy - new challenges), Emigration Affairs and Contacts with Poles Abroad Committee at the Senate of the Republic of Poland, Session on 18 March 2014.

${ }^{36} 150$ duizend inwoners van poolse herkomst (150 thousand inhabitants of Polish origin), 13 June 2016, https://beta.volkskrant.nl/nieuws-achtergrond/poolse-migranten-zijnsteeds-vaker-van-plan-in-nederland-te-blijven $\sim$ bc10c806/?utm_term $=56238 \& u$ tm campaign $=20180424 \% 7$ Cochtend $\& u$ tm_medium $=$ email $\&$ ut source $=$ VK\&utm_content $=$ Poolse $\% 20$ migranten $\% 20$ integreren $\% 20$ moeilijk $\% 20 \mathrm{in} \% 2 \overline{0}$ 
Among Poles who lived in the Netherlands in 2015, only $11 \%$ had full-time employment, while others were either employed flexi-time (58\%) or unemployed $31 \% .{ }^{37}$ This shows how vulnerable and unstable the position of Polish employees is on the Dutch labour market and how their income compares to that of native Dutch. It is worth emphasising that as many as $50 \%$ of Poles constitute cheap labour force that belongs within the lowest segment of the labour market. Consequently, the average income per household in Polish and non-Western immigrant families (e.g. Turks and Moroccans) is EUR 18,300 compared to EUR 25,500 in Dutch households. As already mentioned, $17 \%$ of Poles live in poverty compared to $19 \%$ of non-Western immigrants and only $5 \%$ of native Dutch. ${ }^{38}$ Figures describing poverty among children are similar, with $24 \%$ of Polish minors (up to 18 years of age) living in low-income families compared to $25 \%$ of those in non-Western immigrant families and only $7 \%$ of those in native Dutch households. ${ }^{39}$ Interestingly, nearly $1.8 \%$ of Poles residing in the Netherlands apply for social benefits compared to $2.6 \%$ of Dutch citizens. ${ }^{40}$ It is worth noting that $65 \%$ of employed Poles (aged 1564) remain in the employment relationship for at least 12 hours a week. Otherwise many Poles opt for self-employment. In 2008-2014, the number of Polish employees doubled in the construction sector. ${ }^{41}$

One of the problems experienced by Poles in the Netherlands is related to the form of their employment. In total, $35 \%$ of them are in temporary employment recognised as less attractive than the permanent one (e.g. lack of social security, no pension prospects). Compared to non-Western immigrants and native Dutch (28\% and $17 \%$, respectively), Poles are the least privileged group in this respect. According to SCP, $2 \%$ of Poles receive social assistance benefits from the state. Compared to non-Western immigrants (12\%) and native Dutch (2\%), they are not

Nederland,\%20maar\%20zijn\%20toch\%20steeds\%20vaker\%20van\%20plan\%20om\%20 te\%20blijven\&ctm_ctid=00a5f9469946e74995011c4af273a7f3 (access 27.04.2020).

${ }_{37}$ Een op de $\overline{d r i e}$ Poolse migranten minstens vijf jaar in Nederland (One in three Polish migrants have lived in the Netherlands for at least five years), https://nos.nl/ artikel/2230252-een-op-de-drie-poolse-migranten-minstens-vijf-jaar-in-nederland. html (access 11.03.2020).

38 Jaarrapport integratie 2013, SCP 2014, 11 March 2014.

39 Ibidem.

40 One of the reasons for that may be that they can apply for social benefits only after they have lived in the Netherlands for five years. See: https://www.dutchnews. $\mathrm{nl} /$ news/2018/04/polish-community-in-nl-works-hard-for-low-pay-and-wants-tostay/?utm_source $=$ newsletter $($ access 25.04 .2020$)$.

41 https://www.cbs.nl/nl-nl/nieuws/2017/05/meer-personen-uit-oost-europa-aanhet-werk-in-nederland (access 3.03.2020). 
a particular burden on the Dutch budget in this area. The situation is similar in terms of unemployment benefits $(3.5 \%$ of Poles vs. $3 \%$ of non-Western immigrants and $2.5 \%$ of native Dutch) and benefits due to incapacity for work $(2.2 \%$ of Poles vs. $7 \%$ of non-Western immigrants and $7 \%$ of native Dutch). ${ }^{42}$

\section{Dutch Tolerance in Crisis?}

Dutch tolerance is a result of the country's history which led to the emergence of a socially cohesive albeit not homogeneous society. As Korzewski aptly points out, the heterogeneous and internally diversified social structure of the Netherlands is reflected in the plural form of the country's current name, the Netherlands, or more specifically, Koninkrijk der Nederlanden (the Kingdom of the Netherlands), and its historical names, such as de Nederlanden in Latin (in use until the $12^{\text {th }}$ century), Republiek der Zeven Verenigde Nederlanden (the Republic of the Seven United Provinces, 1581-1795), or De Lage Landen (the Low Countries or the Low Lands). ${ }^{43}$ The country's specific geographical location (much of its land lies below the sea level) contributed to shaping Dutch society in the spirit of pragmatic approach to problem solving and the need for cooperation and mutual respect.

Dutch tolerance is therefore a result of the unique geographical, political, economic and religious pluralism of these lands. ${ }^{44}$ It manifested itself along with the idea of complete cultural and social isolation. Put forward in the $19^{\text {th }}$ century by orthodox Calvinists, it assumed "sovereignty in one's own domain", which Korzewski describes as "creating an 'alternative' and self-sufficient Calvinist world that would exist next to or 'parallelly' to other ideological worlds". ${ }^{45}$ It was undoubtedly one of the "cornerstones" of the pillarisation (in Dutch: Verzuiling) of Dutch society, a system that emerged at the end of the $19^{\text {th }}$ century, where the society was divided based on ideological criteria into four pillars: Protestant, Catholic, socialist and liberal; or correspondingly, into two segments: religious and secular. ${ }^{46}$ This unique social system was maintained in its unchanged form until the 1970s, but as Vink points out some of its manifestations are visible even

42 Jaarrapport integratie 2013, SCP 2014, 11 March 2014.

${ }^{43} \mathrm{M}$. Korzewski, O tolerancji w spoteczeństwie i prawie holenderskim (On tolerance in society and Dutch law), Zakład Wydawniczy “Nomos”, Kraków 2005, pp. 93-94.

${ }^{44}$ Ibidem, passim.

${ }^{45}$ Ibidem, pp. 159-160.

46 A. Lijpart, The politics of accomodation: pluralism and democracy in The Netherlands, University of California Press, Berkeley 1968, p. 188. 
today (e.g. in strategies of the policy towards ethnic minorities). ${ }^{47}$ The policy towards foreigners living in the Netherlands was developed based on the idea of tolerance. However, is has undergone systematic changes in the recent years, turning into one of the most restrictive policies in Europe. The attitude of the Dutch society itself has also changed. Next to tolerance and approval of multiculturalism, increasingly frequent acts of intolerance and even discrimination are being reported with respect to ethnic and national minorities. ${ }^{48}$

A survey conducted by Ipsos shows that according to the majority of Dutch people (55\%), the number of immigrants living in the Netherlands is too high. Other studies reveal that representatives of minority groups are nowadays more discriminated against than 20 years ago. ${ }^{49}$ The issue of discrimination is perceived by Dutch society as a serious problem, particularly in the light of the last few years. Geert Wilders, Leader of the Party for Freedom (in Dutch: Partij Voor de Vrijheid, or PVV), known for its stringent anti-immigration policy, who openly insults ethnic minorities, is often blamed for the current situation. However, it would be an oversimplification to adopt only this perspective to explain the attitude of the Dutch towards foreigners. In fact, in the eyes of the public the issue of immigrants and their integration started growing into a major social problem along with the arrival of larger numbers of refugees/economic immigrants compared to previous decades. ${ }^{50}$

According to the European Commission against Racism and Intolerance (ECRI), measures taken by Mark Rutte's government to combat discrimination due to skin colour, ethnic origin or religion are not sufficiently effective. The Commission blames it on the lack of concrete and decisive actions from the state to eliminate intolerant behaviour, and shifting the government's responsibility to other institutions (e.g. municipalities, non-profit institutions, etc.). ${ }^{51}$ There are many organisations in the Netherlands (foundations, associations, institutes) that work for the ex-

${ }^{47}$ M. Vink, Dutch multiculturalism: Beyond the pillarisation myth, "Political Studies Review”, no. 5/2007, pp. 337-350.

${ }^{48}$ European Islamophobia Report 2016, SETA, Foundation for Political, Economic and Social Research, Istanbul, Washington, Cairo 2016.

${ }^{49}$ J. de Ridder, I. Andriessen, P. Dekker, Nederlanders dubel over discriminatie (Dutch's duplicate approach to discrimination), "Burgerperspectieven", no. 2/2017, Sociaal en Cultureel Planbureau, 29 June 2017, p. 36.

${ }^{50} \mathrm{H}$. Schmeets, M. van Hoof, Ontwikkelingen in ervaren nationale problemen (Development in experienced national problems), 2010-2014, Bevolkings trends, No 6, CBS, The Hague 2016.

${ }^{51}$ More in: Foundation for Political, Economic and Social Research, Istanbul, Washington, Cairo 2016. 
cluded and discriminated. In the light of the rising numbers of incidents related to unequal treatment of persons from minority groups, a number of social campaigns and civic initiatives have been undertaken in the recent years to prevent similar situations. The need for such grassroot actions indicates that the problem does exist and, which is just as important, that people want to fight it.

Mass media (including social media), political parties (including the newly founded Denk and Art1) and citizens themselves (e.g. volunteers) have joined the debate. It is a certain paradox that despite lower acceptance levels towards foreigners among the Dutch, the number of employees representing non-profit institutions working for immigrants is rising. This shows that Dutch society is increasingly more aware of various forms of discrimination and related risks. Inequality of treatment, perceived as a negative phenomenon by the majority of Dutch people $(68 \%)$, is particularly visible in the labour market, and - as pointed out by the respondents - it has been more and more common in the recent years. ${ }^{52} \mathrm{On}$ the other hand, denial of discrimination and unequal treatment may also be observed in Dutch society, with $72 \%$ of Dutch respondents believing that many situations described as "discriminatory" are "exaggerated" and do not always correspond to reality. ${ }^{53}$

A well-known Dutch historian, Ian Buruma, refers to tolerance as a phenomenon that denotes indifference, while emphasising that it is still better than intolerance which tends to resort to violence. On the other hand, being tolerant alone sometimes is not enough..$^{54}$ The etymology of the word "to tolerate" (in Latin: tolerare) seems to confirm this because "to tolerate" means nothing more than "to endure, to put up with someone/something that one cannot accept". In other words, tolerance is a form of lesser evil because it means "only" indifference. With this in mind, Buruma compares the Netherlands to an elite club that is based on specific (national) regulations arising from a "sentimental monarchism" and a "sense of family community" (in Dutch: Gezelligheid). ${ }^{55}$ It is precisely this sense of conviviality that makes it so difficult, particularly for immigrants, to become a member of this "family". According to the

52 J. de Ridden, I. Andriessen, P. Dekker, op. cit., p. 36.

${ }_{53} \mathrm{H}$. van Dalen, Waroom waant Nederland zich Europees kampioen discriminatie? (Why does the Netherlands win European discrimination champion), http://www.mejudice. $\mathrm{nl} /$ artikelen/detail/waarom-waant-nederland-zich-europees-kampioen-discriminatie (access 18.03.2020)

54 I. Buruma, Granice tolerancji (Tolerance limits), 14 October 2016, http://www. newsweek.pl/europa/granice-tolerancji,44920,1,1.html (access 8.05.2020).

${ }^{55}$ Ibidem. 
historian, this specific understanding of multiculturalism by the Dutch results from the fact that they tend to perceive immigrants in cultural categories rather than the institutional and legal ones. It may be the effect of the pillarisation system that instilled this way of thinking into Dutch society.

Finally, I would like to briefly discuss research conducted on native inhabitants of the Netherlands regarding their level of tolerance towards ethnic minorities living in their country. Studies carried out in 2008 in 46 European countries showed that the Netherlands ranked first as a country with the highest levels of acceptance towards newcomers (95\%). Compared to figures reported by SCP (2017), a significant drop may be observed (31\%). ${ }^{56}$ This seems to be a result of several factors - notably, terrorist attacks in the United States and Europe as well as a number of incidents in the Netherlands themselves (the assassinations of politician Pim Fortuyn and film director Theo van Ghog are still fresh in Dutch memory), further exacerbated by the economic crisis (e.g. in the critical year of 2013 the unemployment rates in the Netherlands reached $6.6 \%)^{57}$ and refugee crisis - all of which seem to have considerably stretched the tolerance of the Dutch towards "others". Once again, one cannot forget that migration and integration of immigrants are currently listed among the greatest social concerns in the Netherlands. ${ }^{58}$

\section{Conclusions}

According to SCP, Dutch society has become critical about immigrants living in the Netherlands because it sees in their presence more losses than benefits. As many as $62 \%$ of Dutch people think this way. Twothirds of Dutch citizens point to alarming consequences related to the influx of immigrants from CEE, linking their presence to increased crime and growing problems in the public sphere. Among the native Dutch,

${ }^{56}$ H. Wansink, Zijn Nederlanders toleranter geworden tegenover migranten? (Have the Dutch become more tolerant towards migrants?), Volkskrant, 13 December 2017, https:// www.volkskrant.nl/columns-opinie/zijn-nederlanders-toleranter-geworden-tegenover-migranten- bebf8a3f/ (access 16.12.2019).

57 https://www.cbs.nl/nl-nl/nieuws/2017/16/werkloosheid-daalt-verder (access 22.06.2019). See also: T. Overdijk, Werkloosheid in Nederland hoger dan voor crisis (Unemployment in the Netherlands higher than before crisis), https://www.places.nl/nieuws/werving\&-selectie/werkloosheid-in-nederland-hoger-dan-voor-de-crisis/ (access 18.01.2020).

${ }^{58}$ D. Jansen, Immigratie en integratie het grootse probleem van Nederland (Immigration and integration the biggest problem in the Netherlands), https://demonitor.kro-ncrv. $\mathrm{nl} /$ artikelen/immigratie-en-integratie-het-grootste-probleem-van-nederland (access 21.06.2019). 
$58 \%$ believe that immigrants constitute an economic encumbrance on the state because of their reliance on social benefits, while $47 \%$ believe that immigrants from the "East" take jobs that belong to the Dutch. ${ }^{59}$ Such attitude is not conducive to the integration of immigrants and, more importantly, can lead to unnecessary conflicts. ${ }^{60}$ The problem of discrimination in the Netherlands applies to both non-Western immigrants and those who came to the Netherlands from CEE.

The percentage of Poles who feel unequally treated increased from $38 \%$ in 2009 to $46 \%$ in $2017 .{ }^{61}$ The sense of security of Poles living in the Netherlands is gradually decreasing also as a result of reduced acceptance levels in the host society. In $2009,42 \%$ of Poles considered the Netherlands their second homeland, while in 2015 this number dropped to $36 \%$. Despite such attitude Poles declare their willingness to stay in the Netherlands for the next five years or longer. ${ }^{62}$

According to Małgorzata Bos-Karczewska, a long-time advocate of Poles living in the Netherlands, the debate on migration (which often creates a negative image of new immigrants) has an adverse effect on the situation of Polish citizens. She says that it is difficult for them to shed the label of "residents that generate problems" or "the poor from behind the Iron Curtain who parasitise on our [i.e. Dutch - VGR] wellbeing". Because of this Polish immigrants find it hard to feel welcome. ${ }^{63} \mathrm{In}$ addition, Poles' bitterness is related to difficulties on the labour market. The activist points out that the Dutch government is partly responsible

${ }^{59}$ M. Bos-Karczewska, Sytuacja polskiej migracji zarobkowej w Holandii a polityka państwa - nowe wyzwania (The situation of Polish labour migration in the Netherlands and state policy - new challenges), Emigration Affairs and Contacts with Poles Abroad Committee at the Senate of the Republic of Poland, Session on 18 March 2014, from: Burgerperspectieven 2013/4 SCP, December 2013.

${ }^{60} 20$ tot 40 procent migranten ervaart discriminatie bij banenjacht $(20$ to 40 percent of migrants experience discrimination in job hunting), https://www.nu.nl/economie/3683563/2040-procent-migranten-ervaart-discriminatie-bij-banenjacht.html (access 8.04.2020).

${ }^{61}$ Polish community in NL works hard for low pay and wants to stay, 24 April 2018, https://www.dutchnews.nl/news/2018/04/polish-community-in-nl-works-hard-forlow-pay-and-wants-to-stay/?utm_source=newsletter (access 25.04.2020).

${ }^{62}$ S. van Walsum, Poolse migranten zijn steeds vaker van plan in Nederland te blijven (Polish migrants are increasingly planning to stay in the Netherlands), 24 April 2018, https://beta.volkskrant.nl/nieuws-achtergrond/poolse-migranten-zijn-steeds-vaker-van-plan-in-nederlandte-lijven $\sim$ bc10c806/?utm_term $=56238 \& u$ tm_campaign $=20180424 \% 7$ Cochtend \&utm medium $=$ email \&utm_userid $=\& u t m \_s o u r c e=V K \& u t m \_$content $=$Poolse $\% 20$ migranten $\% 20$ integreren $\% 20$ moeilijk\%20in $\% 20$ Nederland, $\% 20$ maar\%20zijn $\% 20$ toch $\% 20$ steeds\%20vaker\%20van\%20plan\%20om\%20te\%20blijven\&ctm_ctid=00a5f946 9946e74995011c4af273a7f3 (access 22.04.2020).

63 W. Willems, H. Verbeek, op. cit., p. 323. 
for this, as it does not pay much attention to improving the situation of immigrants in terms of employment. For example, the authorities do not take sufficient action to combat the exploitation of immigrant workers by employers, temporary work agencies and dishonest landlords. ${ }^{64}$ BosKarczewska observes that the Dutch government does not put enough emphasis on integration policy, including regulations regarding newcomers' accommodation, training and welfare.$^{65}$ At the same time, she criticises Poles for their careless behaviour - for example, in cases when they do not complete the necessary formalities to be able to stay in the Netherlands and are then ordered to leave the country within 14 days. ${ }^{66}$

Following the "example" of its predecessors, the current Dutch government does not seem to notice the problem of immigrants settling down in the Netherlands and continues to perceive their stay as temporary. Despite many changes and reforms, the immigration and integration policy is based on one element that does not change: treating immigrants as cheap labour force in a short-term perspective. However, it seems that regardless of the duration of their employment and stay in the Netherlands, they constitute a potential that is worth using and analysing not only in terms of risks but also opportunities. As Wim Willems says, it is time to forget "the myth of immigrants going back to their homelands - rather than use their origin against them we should start investing in them". ${ }^{67}$

\section{References}

150 duizend inwoners van poolse herkomst (50 thousand inhabitants of Polish origin), 13 June 2016, https://www.cbs.nl/nl-nl/nieuws/2016/24/150-duizend-inwoners-van-poolse-herkomst (access 27.04.2020).

20 tot 40 procent migranten ervaart discriminatie bij banenjacht (20 to 40 percent of migrants experience discrimination in job hunting), https://www.nu.nl/ economie/3683563/20-40-procent-migranten-ervaart-discriminatiebij-banenjacht.html (access 8.05.2020).

73. rocznica wyzwolenia Bredy przez Dywizje gen. Stanistawa Maczka (73rd anniversary of the liberation of Breda by the Division of General Stanistaw

${ }^{64}$ See: M. Pacek, Migracje, mobilność, wielokulturowość - Holandia wobec problemów migracyjnych (Migration, mobility, multiculturalism - The Netherlands towards migration problems), "Studia Europejskie", no. 4/2016, pp. 10-12, http://www.ce.uw.edu.pl/pliki/ pw/4-2016_pacek.pdf (access 9.05.2020).

${ }^{65}$ W. Willems, H. Verbeek, op. cit., p. 323.

${ }^{66}$ M. Bos-Karczewska: Holendrom zależy na Polakach (The Dutch care about Poles), http://www.rp.pl/Polityka/170319257-Malgorzata-Bos-Karczewska-Holendrom-zalezy-na-Polakach.html (access 15.03.2020).

${ }_{67}$ W. Willems, H. Verbeek, op. cit., p. 324. 
Maczek), http://dzieje.pl/artykulyhistoryczne/rocznica-wyzwoleniabredy-przez-1-dywizje-pancerna-gen-maczka (access 12.04.2020).

Article 3(2) of the Treaty on European Union (TEU); Art. 4(2a), art. 20, 26 and 45-48 of the Treaty on the Functioning of the European Union (TFEU).

Balicki J., Amsterdamskie ABC (Amsterdam ABC), Wydawnictwo Iskry, Warszawa 1974.

Bos-Karczewska M., Sytuacja polskiej migracji zarobkowej w Holandii a polityka panstwa - nowe wyzwania (The situation of Polish labor migration in the Netherlands and state policy - new challenges), Emigration Affairs and Contacts with Poles Abroad Committee at the Senate of the Republic of Poland, Session on 18 March 2014.

Bruquetas-Callejo M., Garcés-Mascareñas B., Penninx R., Scholten P., Migration policymaking in Europe: the dynamics of actors and contexts in past and present, The case of the Netherlands, Amsterdam University Press, Amsterdam 2011.

“Burgerperspectieven”, no. 4/2013, SCP, December 2013.

Buruma I., Granice tolerancji (Tolerance limits), "Newsweek" 14 October 2016, http://www.newsweek.pl/europa/granice-tolerancji,44920,1,1.html (access 8.05.2020).

Central Archives of Modern Records (AAN), Ministry of Foreign Affairs, General Representative for Repatriation, Letter No 503 from the Central European Department of the Ministry of Foreign Affairs to the Polish Military Mission in Berlin dated 16 October 1947.

Dalen van H., Waroom waant Nederland zich Europees kampioen discriminatie? (Why does the Netherlands win European discrimination champion), http://www.mejudice.nl/artikelen/detail/waarom-waant-nederlandzich-europees-kampioen-discriminatie (access 18.03.2020).

Directive 2004/38/EC on the right of citizens of the Union and their family members to move and reside freely within the territory of the Member States.

Eder W., Diaspora polska w Belgii i Holandii (Polish diaspora in Belgium and the Netherlands), in: Polska diaspora (Polish diaspora), eds. K. Kaczmarski, M. Krzysztofiński, Kraków 2003.

Eder W., Polonia w krajach Beneluksu - Holandia (Polish community in the Benelux - The Netherlands), in: Polonia w Europie (Polonia in Europe), ed. B. Szydłowska-Ceglowa, Poznań 1992.

Een op de drie Poolse migranten minstens vijf jaar in Nederland (One in three Polish migrants have lived in the Netherlands for at least five years), https:// nos.nl/artikel/2230252-een-op-de-drie-poolse-migranten-minstensvijf-jaar-in-nederland.html (access 11.03. 2020). 
European Islamophobia Report 2016, SETA, Foundation for Political, Economic and Social Research, Istanbul, Washington, Cairo 2016.

https://nos.nl/artikel/2228737-polen-blijven-steeds-vaker-in-nederland. html (access 16.05.2020).

https://www.cbs.nl/nl-nl/nieuws/2016/24/150-duizend-inwoners-van-poolse-herkomst (access 27.04.2020).

https://www.cbs.nl/nl-nl/nieuws/2017/05/meer-personen-uit-oost-europaaan-het-werk-in-nederland (access 3.04.2019).

https://www.dutchnews.nl/news/2018/04/polish-community-in-nl-workshard-for-low-pay-and-wants-to-stay/?utm_source=newsletter (access 25.04.2020).

https://www.kis.nl/sites/default/files/bestanden/Publicaties/Poolse-arbeidsmigranten-in-Nederland.pdf (access 12.05.2020).

Faarrapport integratie 2013, SCP 2014, 11 March 2014.

Jansen D., Immigratie en integratie het grootse probleem van Nederland (Immigration and integration the biggest problem in the Netherlands), https://demonitor.kro-ncrv.nl/artikelen/immigratie-en-integratie-het-grootsteprobleem-van-nederland (access 21.06.2019).

Korzewski M., O tolerancji w spoteczeństwie i prawie holenderskim (On tolerance in society and Dutch law), Zakład Wydawniczy "Nomos", Kraków 2005.

Lijphart A., The politics of accommodation: pluralism and democracy in The Netherlands, University of California Press, Berkeley 1968.

Nadolny A., Polonia Holenderska (Polish community in the Netherlands), "Studia Polonijne", vol. I/1976.

Pacek M., Migracje, mobilność, wielokulturowość - Holandia wobec problemów migracyjnych (Migration, mobility, multiculturalism - The Netherlands towards migration problems), "Studia Europejskie", no. 4/2016.

Polish community in NL works hard for low pay and wants to stay, 24 April 2018, https://www.dutchnews.nl/news/2018/04/polish-community-in-nlworks-hard-for-low-pay-and-wants-to-stay/?utm_source $=$ newsletter (access 25.04.2020).

Polonia Zagraniczna 1929-1954. Ksiega Pamiatkowa w 25-lecie istnienia Światowego Zwiazku Polaków z Zagranicy (Commemorative Book on the 25th anniversary of the World Union of Poles from abroad), London 1956.

Radomski J.A., Demobilizacja Polskich Sit Zbrojnych na Zachodzie w latach 1945-1951 (Demobilization of the Polish Armed Forces in the West in 19451951), Księgarnia Akademicka, Kraków 2009.

Regulation (EC) No 883/2004 on the coordination of social security systems and Regulation (EC) No 987/2009 laying down the procedure for implementing Regulation (EC) No 883/2004. 
Regulation (EU) No 492/2011 on freedom of movement for workers within the Union.

Ridder de J., Andriessen I., Dekker P., Nederlanders dubbel over discriminatie (Dutch's duplicate approach to discrimination), "Burgerperspectieven", no. 2/2017, Sociaal en Cultureel Planbureau, 29 June 2017.

Schmeets H., van Hoof M., Ontwikkelingen in ervaren nationale problemen (Development in experienced national problems), 2010-2014, Bevolkings trends, no. 6, CBS, The Hague 2016.

Śledziński K., Czarna Kawaleria. Bojowy szlak pancernych Maczka (Black Cavalry. Maczek's armored battle route), Wydawnictwo Znak, Kraków 2011.

Tekort aan mijnwerkers. Het Nederlandse element in mijnstreek gaat achteruit (Shortage of miners. The Dutch element in the mining region is deteriorating), „Limburger Koerier”, 13 August 1929.

Tomkowski Z., Z dziejów Polonii w Europie. Geneza i charakterystyka Polonii (From the history of the Polish community in Europe. The origin and characteristics of Polonia), http://ziemia.pttk.pl/Ziemia/Artykul_1974_003. pdf, p. 20 (access 21.01.2020).

Vink M., Dutch multiculturalism: Beyond the pillarisation myth, "Political Studies Review", no. 5/2007, DOI: https://doi.org/10.1111/j.14789299.2007.00134.x

Walsum van S., Poolse migranten zijn steeds vaker van plan in Nederland te blijven (Polish migrants are increasingly planning to stay in the Netherlands), 24 April 2018, https://www.volkskrant.nl/nieuws-achtergrond/poolse-migranten-zijn-steeds-vaker-van-plan-in-nederland-te-blijven $\sim$ bc10c806/ (access 22.04.2020).

Wansink H., Zijn Nederlanders toleranter geworden tegenover migranten? (Have the Dutch become more tolerant towards migrants?), Volkskrant, 13 December 2017, https://www.volkskrant.nl/columns-opinie/zijnnederlanders-toleranter-geworden-tegenover-migranten- $\sim$ bebf8a3f/ (access 16.12.2019).

Willems W., Verbeek Hanneke, Sto lat tesknoty. Polacy w Holandii (One hundred years of longing. Poles in the Netherlands), Wydawnictwo DIG, Warsaw 2014.

Żelichowski R., Stosunki polsko-holenderskie w Europie pojattańskiej (Polish-Dutch relations in post-Yalta Europe), ISP PAN, Warsaw 2014. 